\title{
(2) \\ New Technologies and the Protection and Promotion of Traditional Cultural Expressions
}

\author{
Mira Burri Nenova*
}

\begin{abstract}
New technologies, in particular those stemming from digitization, allow amongst other things the production of perfect copies, instantaneous and ubiquitous distribution of and easy access to information with no real location restrictions. The effects of these technological advances have largely been perceived as negative for the protection of Traditional Cultural Expressions (TCE), both because of the peculiarities of the digital networked environment and because of the lack of appropriate intellectual property protection models for TCE. The purpose of this article is, while accounting for the diversity and complexity of issues related to TCE, to reveal a more positive side of digital technologies. It shows the potential of these to be proactively applied and the further reaching possibilities for designing an efficient multi-level and multi-faceted toolbox for the protection and promotion of TCE in the digital ecology.
\end{abstract}

\footnotetext{
Senior research fellow, World Trade Institute, University of Bern and alternate leader of the research project "diversity: The Legal Protection of Cultural Diversity in a Digital Networked Environment", which is part of the Swiss National Centre of Competence in Research "International Trade Regulation", sponsored by the Swiss National Science Foundation. E-mail: Mira.Burri@wti.org
}

(c) 2007 Mira Burri Nenova. This article was originally published as NCCR Trade Regulation Working Paper No. 22/2007. Reprinted with permission.

Source: www.nccr-trade.org 
(1) echnologies have often been seen as a peril for traditional cultural expressions (TCE) and as an inhibitor of their protection. The first reason for this angst, whose legitimacy will be one of the issues discussed in this paper, is that new technologies are indeed viewed as the very epitome of globalisation forces - both as driving and deepening the process of globalisation itself and as a means of spreading its effects. Frequently made statements in this regard (and widely supported ones too) are that, "[t]he distinct and diverse qualities of the world's multiple cultural communities are threatened in the face of uniformity brought on by new technologies and the globalization of culture and commerce". "I "Increasingly, traditional knowledge, folklore, genetic material and native medical knowledge flow out of their countries unprotected by intellectual property, while works from developed countries flow in, well protected by international intellectual property agreements, backed by the threat of trade sanctions". ${ }^{2}$

A second reason for the perceived negative effects of new technologies lies in their very nature, since they allow, among other things, instantaneous access to information, reproduction of the original without loss of quality and data transport with the speed of light at an ever decreasing price. ${ }^{3}$ A clear recognition of this is paragraph 31 of General Comment No 17, ${ }^{4}$ which explicitly adds to the obligation to protect author's rights ${ }^{5}$ the prevention of "unauthorized use of scientific, literary and artistic productions that are easily accessible or reproducible through modern communication and reproduction technologies" ${ }^{6}$

It is the purpose of this work to put these "modern technologies" into a new perspective by undertaking firstly, a more refined enquiry into their characteristics and effects, and secondly, by broadening the "picture" within which the relationship "new technologies - TCE" is so easily (and a bit hurriedly) fitted into. Profiting from the other contributions to this volume, ${ }^{7}$ we do not need to depict all the underlying TCE issues and/or the legal tools at local, national, regional and international level, attempting to address them. We shall thus focus our analysis on the first part of the equation "new technologies - TCE" and seek to pinpoint the impact of selected new technologies upon TCE, and above all, upon the environment, where TCE are to be protected and promoted. 
The analysis will be structured in three parts. Part One briefly outlines our starting premises in the context of TCE. The second part of the enquiry concentrates on new technologies: (i) firstly, by addressing the question, which begs a clarification from the very beginning (even in the title) of this work, namely which "new technologies" we precisely consider; (ii) secondly, by analysing their impact on markets, consumer and business behaviour patterns; and (iii) thirdly and most importantly, by examining the repercussions of these for the processes of formation, production and expression of culture. Part Three draws conclusions and suggests an adjusted basic conceptual framework for the relationship "new technologies - TCE".

\section{Starting Premises}

\subsection{On Complexity}

Before we begin with the substantive analysis of new technologies and in order to clarify the methodology applied herein, we would like to stress one particular characteristic of any discussion on any TCE-related issue, namely its complexity.

TCE is indeed a terminological shortcut for grouping together a wide variety of staggeringly diverse by nature, meaning and form expressions, both tangible and intangible. ${ }^{8}$ TCE depicts an extremely complex reality whose limits are indefinable and whose building elements may often be in themselves complex notions, such as the concept of "dreaming" (or "dreamtime") of Australia's indigenous peoples. ${ }^{9}$ TCE are also not a static but a highly dynamic, living system, which is constantly in process of renegotiation, innovation and creation. ${ }^{10}$ Furthermore, it should be acknowledged that, "[i]ndigenous peoples regard all products of the human mind and heart as interrelated, and as flowing from the same source: the relationships between the people and their land, their kinship with the other living creatures that share the land, and with the spirit world". " Accordingly diverse are the needs and expectations of the TCE custodians in terms of demanded protection. They range from Intellectual Property (IP) protection to support economic development and prevent unwanted use by others ${ }^{12}$ to land and selfdetermination claims. ${ }^{13}$

The two most relevant fields of law, when one talks about the protection and promotion of TCE are the Intellectual Property Rights (IPR) and the human rights 
frameworks, both nationally and internationally. 14 These legal domains are by no means simple hierarchical structures but are defined and shaped by complex relationships, trade-offs, balances, internal inefficiencies and conflicts.

The IPR model 15 was put in place "To promote the Progress of Science and useful Arts, by securing for limited Times to Authors and Inventors the exclusive Right to their respective Writings and Discoveries". 16 IP protection is thus meant to encourage persons to become more productive by allowing them to capture some of the benefits of their useful behaviour. It involves however a trade-off between the granted author's limited monopoly and the need of society as a whole to make use of authors' creativity and innovation. The broad palette of increasingly sophisticated 17 IP tools allows for flexibility and can be used "to protect both traditional and new forms of symbolic value produced in particular places as they circulate in global commodity markets".18 Still, IP protection shows substantial deficiencies. Such limitations are embedded in the nature and the mechanisms of IP protection and relate to the centrality of authorship, originality and mercantilism to the "Western" IP model. A large number of non-Western, collaborative or folkloric modes of production are consequently left outside the scope of IP protection. 19 There is further often a dissonance (i) between certain IP and traditional concepts, such as "ownership" or "author" and their non-existence under the customary laws of indigenous communities; (ii) between the fixation requirement in copyright and the intangible and oral character of some traditional expressions; (iii) between the novelty requirement and the limited term of IP protection and the perpetual nature of TCE. ${ }^{20}$

In the IP domain and beyond the specific characteristics of TCE, there are furthermore complex relationships between the private and the public, and between creativity, innovation and the IP incentives given to promote them. "In general, systems built around the author paradigm tend to obscure or undervalue the importance of the 'public domain', the intellectual and cultural commons from which future works will be constructed. Each intellectual property right, in effect, fences off some portion of the public domain, making it unavailable to future creators". ${ }^{21}$ There is thus a need to strike a balance between the private interests of authors and the public interest in enjoying broad access to their productions ${ }^{22}$ - a balance that is in itself a complex high-wire act and that may be vital, as we discuss below, for the sustainability of culture, including traditional one and for creativity in particular. 
As for the latter, the content industries are constantly asserting that IPR is the guarantee of innovation and creativity and thereby, the single most important prerequisite for a vibrant culture. While IP protection certainly fulfils essential economic functions in cultural production and distribution, ${ }^{23}$ a direct causality between IPR (or stronger IPR) and creativity is equivocal, and IP protection may even trigger systemic harm. ${ }^{24}$ The US Supreme Court did recognise this in part, noting in Grokster that, "[t]he more artistic protection is favored, the more technological innovation may be discouraged". ${ }^{25}$ Beyond this, some copyright scholars observing the process of creativity more closely, argue that it is the creative play that is of primary importance for the artistic and intellectual innovation ${ }^{26}$ - a play that may very well be obstructed by contemporary (and ever strengthening) ${ }^{27}$ IP regimes.

Turning to the complexity of the human rights framework, we need to firstly reiterate the well-known dictum of the Vienna Declaration that, "[a]ll human rights are universal, indivisible, interdependent and interrelated".28 This interlinkage and interdependence is in its own right fairly complex. Furthermore, even if we take one single right, for instance, the core for TCE protection right of everyone to benefit from the protection of the moral and material interests resulting from any scientific, literary or artistic production of which he is the author, as enshrined in Article 15(1)(c) of the International Covenant on Economic, Social and Cultural Rights (CESCR),29 we see that the stemming obligations are manifold. As General Comment No 17 clarifies, the State's obligations flowing from this right encompass three distinct undertakings - to respect, protect and fulfil. In turn, "[t]he obligation to respect requires States parties to refrain from inferfering directly or indirectly with the enjoyment of the right to benefit from the protection of the moral and material interests of the author. The obligation to protect requires States parties to take measures that prevent third parties from interfering with the moral and material interests of authors. Finally, the obligation to fulfil requires States to adopt appropriate legislative, administrative, budgetary, judicial, promotional and other measures towards the full realization of Article 15, paragraph 1(c)". ${ }^{30}$

Furthermore, the right formulated in Article 15(1)(c) CESR serves a particular purpose "to encourage the active contribution of creators to the arts and sciences and to the progress of society as a whole. As such, it is intrinsically linked to the 
other rights recognized in Article 15 of the Covenant, i.e. the right to take part in cultural life (Article 15, paragraph 1(a)), the right to enjoy the benefits of scientific progress and its applications (Article 15, paragraph 1(b)), and the freedom indispensable for scientific research and creative activity (Article 15, paragraph 3). The relationship between these rights and Article 15, paragraph 1(c), is at the same time mutually reinforcing and reciprocally limitative". ${ }^{31}$ It is moreover stressed that the realisation of Article 15(1)(c) CESR is "dependent on the enjoyment of other human rights guaranteed in the International Bill of Human Rights and other international and regional instruments, such as the right to own property alone as well as in association with others, the freedom of expression including the freedom to seek, receive and impart information and ideas of all kinds, the right to the full development of the human personality, and rights of cultural participation, including cultural rights of specific groups" ${ }^{32}$

Besides the intrinsic complexity of each of the above legal frameworks, one also needs to acknowledge that they evolve over time and tend to "conquer" new regulatory fields. Despite the distinct theoretical and philosophical roots of human rights and IP regimes, "33 "the recent expansion of the two fields has blurred these distinctions in new and unexamined ways. [...] expand[ing] their scope over time, creating dense 'policy spaces' in which formerly unrelated sets of principles, norms, and rules increasingly overlap in incoherent and inconsistent ways". ${ }^{34}$

The lack of coherence is evident not only from collisions between the IP and the human rights domains. Even recent efforts of the international community, whose drafters were fully aware of the already existing fragmentation, had not succeeded in generating coherence due both to the limitations of the political and diplomatic processes and the limitations of the legal instruments themselves. A much celebrated legal effort that exemplifies this with a particular regard to the protection and promotion of TCE is the Convention on the Protection and Promotion of the Diversity of Cultural Expressions, ${ }^{35}$ adopted at the 33rd Session of the General Conference of UNESCO in 2005.

The UNESCO act set before itself the ambitious objectives, among others, "to protect and promote cultural diversity", "to create the conditions for cultures to flourish and to freely interact in a mutually beneficial manner" and "to give 
recognition to the distinctive nature of cultural activities, goods and services as vehicles of identity, values and meaning". ${ }^{36}$ Despite these admirable goals, the Convention subscribes to an overbroad definition of cultural diversity, ${ }^{37}$ while being ethnocentric in the formulation of the rights of the State parties. ${ }^{38}$ It barely refers to intellectual property rights ${ }^{39}$ and provides no meaningful mechanism for solving conflict of law situations with other international obligations of the States (most notably, these existing under the World Trade Organization agreements). ${ }^{40}$ Since the Convention on Cultural Diversity contains neither specific obligations for the State parties, ${ }^{41}$ nor guidelines on what legitimate cultural diversity-aimed measures are, it remains a mere political striving to protect the national content industries that suspiciously resembles protectionism, and intensifies the already existing discrepancies in the TCE protection domain.

The above sketch revealed only a fraction of the complexity of TCE protection and promotion debates from a legal perspective. It captured neither the confounding complexity of implementation and enforcement, nor the manifold of different national, international and civil society organisations and agencies active in the field. ${ }^{42}$ It is nonetheless sufficiently clear that any effort dealing with TCE protection will be confronted with the complex relationships and interdependencies existing in the above system and its effect will need to be tested against the whole and the likelihood of having multiple, diverse and unexpected repercussions in multiple directions.

\subsection{On Methodology}

Instead of attempting to reduce the above complexity, we introduce and reveal the complexity of a new variable, namely technology. We deem that this variable is particularly important in the environment of TCE because, as we show below, it strongly influences the processes of cultural formation, production, expression, distribution and consumption, and has not been sufficiently accounted for until now. In the following analysis, "the broader significance of information, including the practical, political, and moral impact of its proposed regulation" ${ }^{\prime 43}$ will be acknowledged and its inherent characteristics as non-rivalrous ${ }^{44}$ and as "homeless" 45 taken into account. In light of this and in the context of cultural heritage, Michael F. Brown, suggests to think about "...information ecologically, as a total system of mutually influencing relationships and forces". ${ }^{46}$ Following 
this methodology, albeit in a more doctrinally-neutral manner, we situate the entire discussion of the relationship "new technologies - TCE" in the broad context of complex adaptive systems. ${ }^{47}$ Such systems are complex in that they are diverse and made up of multiple interconnected elements (such as the ones sketched above) and adaptive in that they have the capacity to change and learn from experience. This approach allows us to take into consideration all elements and the multiplicity of forces at play, and avoids the dangers that some positive, though narrowly defined objectives or actions, conflict and/or are influenced by policies formulated elsewhere in society.

\section{New Technologies}

\subsection{Which New Technologies?}

The concept of "new technologies" is indefinitely general and may often be a misnomer. It may in fact be observed that many of the documents tackling TCE protection, take new technologies as a lump and do not define their parameters and/or effects. While the precise limits of the cluster of technologies we shall discuss here may indeed be hard to define, the roots of all phenomena undoubtedly lie in the process of digitisation, as well as in the related emergence of the Internet as a ubiquitous communication and information distribution platform.

Digitisation allows for the expression of each and every type of content (be it audio, video or text) in a line of zeroes and ones and thereby creates a universal code for all information. As a consequence, it is irrelevant to the network whether the transferred data is the video of the Apache sunrise ceremony, a picture of a sacred Aboriginal totem or the latest hip-hop hit - they will all be rendered in zeroes and ones.

The ability of digital systems to handle an ever greater amount of multimedia content at lower and lower cost is a product of the exponential progress in the processing power and memory of microchips. ${ }^{48}$ As a third element of this technological matrix is the perfection and the widespread use of optical fibres, ${ }^{49}$ which substantially enhanced the breadth and capacity of networks ${ }^{50}$ and made the conveyance of digitised information at high speed possible. 
This technological matrix allowed and spurred the development and advancement of the Internet ${ }^{51}$ as a global, publicly accessible network of interconnected computer networks, which transmit data by packet switching using a standard Internet Protocol. This "network of networks" consists of millions of smaller government, academic, business and domestic networks, which carry various information and services (such as electronic mail) and most notably, the world wide web. The latter builds the logical layer of the Internet as a system of interlinked, hypertext documents, which allows us to find web pages, various contents on them and to navigate between them, i.e. to reach out to the application and content layer. ${ }^{52}$

The content layer has become particularly "dense" and miscellaneous with the sophistication of networks and growing adoption of the Internet (especially broadband). ${ }^{53}$ Essentially, everything is online and some things are only online. Different media, such as video gaming, music, radio and newspapers are widely accepted as substitutes for traditional analogue media ${ }^{54}$ and as we discuss below, users engage actively in creating new content independently or as an addition to already existing one.

In the following sections, we focus our attention upon the Internet, taken collectively as network, logical, application and content layers and interchangeably referred to as "digital environment", ${ }^{55}$ and look into the impact of this single most powerful global communication and information platform. ${ }^{56}$ We do so however not in the sense of building some grand theory of the new Network (or) Information Society ${ }^{57}$ but examine narrowly and specifically the effects of digital technologies upon the markets for content and the content production modes, because of their as yet unexplored relevance for TCE and cultural diversity in general.

\subsection{The Impact of New Technologies}

\subsubsection{Repercussions for the Markets for Cultural Content}

\section{A. New Mechanisms/New Choices}

In the not so distant past, the markets for cultural content were dominated by analogue media. People had access to a variety of outlets, such as television or cinema, but not necessarily to a variety of content. Technical advances and the liberalisation and deregulation of media markets made the number of outlets 
even larger (e.g. while in 1989, 90 TV channels were available in the EU15, ${ }^{58}$ in the beginning of 2004, over 860 channels with potential national coverage were broadcast via terrestrial transmitters, satellite or cable). ${ }^{59}$ Paradoxically, the impact of multiple channels have not been positive to diversity. Rather, the variety of content shrunk even more: In the European television market, for instance, the quantity of imported programmes and their costs have continuously soared, ${ }^{60}$ while the quality and the range of programmes have been radically reduced. ${ }^{61}$ The pursuit of a maximisation of profits and a minimisation of financial risks has resulted in "imitation, blandness and the recycling of those genres, themes and approaches regarded as profitable". ${ }^{62}$ The formats and contents of TV programmes, films and shows have become increasingly homogeneous. ${ }^{63}$ TCE in this context have been either re-packaged and commodified, or qualified as "not selling" and marginalised. The emergence of global media giants going beyond national and sectoral boundaries, placing the same content in all available distribution channels and formats, has only aggravated the situation.

The reasons for this rather bleak picture, which exasperates the indigenous communities' fears of appropriation and misappropriation, lies not (or at least not only) in the uniform tastes of the public or the lack of cultural creativity. Simply put, it has to do with the economics of scarcity in media and the nature of distribution of cultural content in a "push", point-to-multipoint mode: To convey it figuratively, where storage and distribution costs are high, the "shelf" place is limited and it makes sense (especially to the large profit-maximising media conglomerates) to put up only those products that sell best - the hits, i.e. uniform content that, subject to the lowest-common denominator, appeals at a certain moment in time to the largest possible audience. ${ }^{64}$

The scope of this work does not allow for a full-fledged analysis of either the economics of media markets, or for a comprehensive critique of the cultural industries. We apply instead a very pragmatic approach: We allow ourselves simply the observation that in these cultural content markets, the sales and correspondingly the consumption are concentrated in a miniscule part of all the available content. Bluntly put, $20 \%$ of the produced and sold content (be it a book, film or song) generate $80 \%$ of all the sales in that market (with a few outstanding blockbusters making a substantial chunk of it). The rest $80 \%$ of existing content never actually make it to TV or cinema screens, the CD or DVD shop shelves, or is shown at an odd hour or sold in a small "world music only" shop. 
One may argue that this is nothing unusual. After all, the $80 / 20$ rule, which was first used to describe the allocation of wealth among individuals, whereby $20 \%$ of the population owns $80 \%$ of the wealth, was formulated by the Italian economist Vilfredo Pareto in 1896. Furthermore, these so-called power laws have been observed in many areas, such as physics, biology, geography, economics and linguistics, and depict a frequent situation of extreme distribution, whereby a relatively small proportion of elements generates a large proportion in distribution. ${ }^{65}$

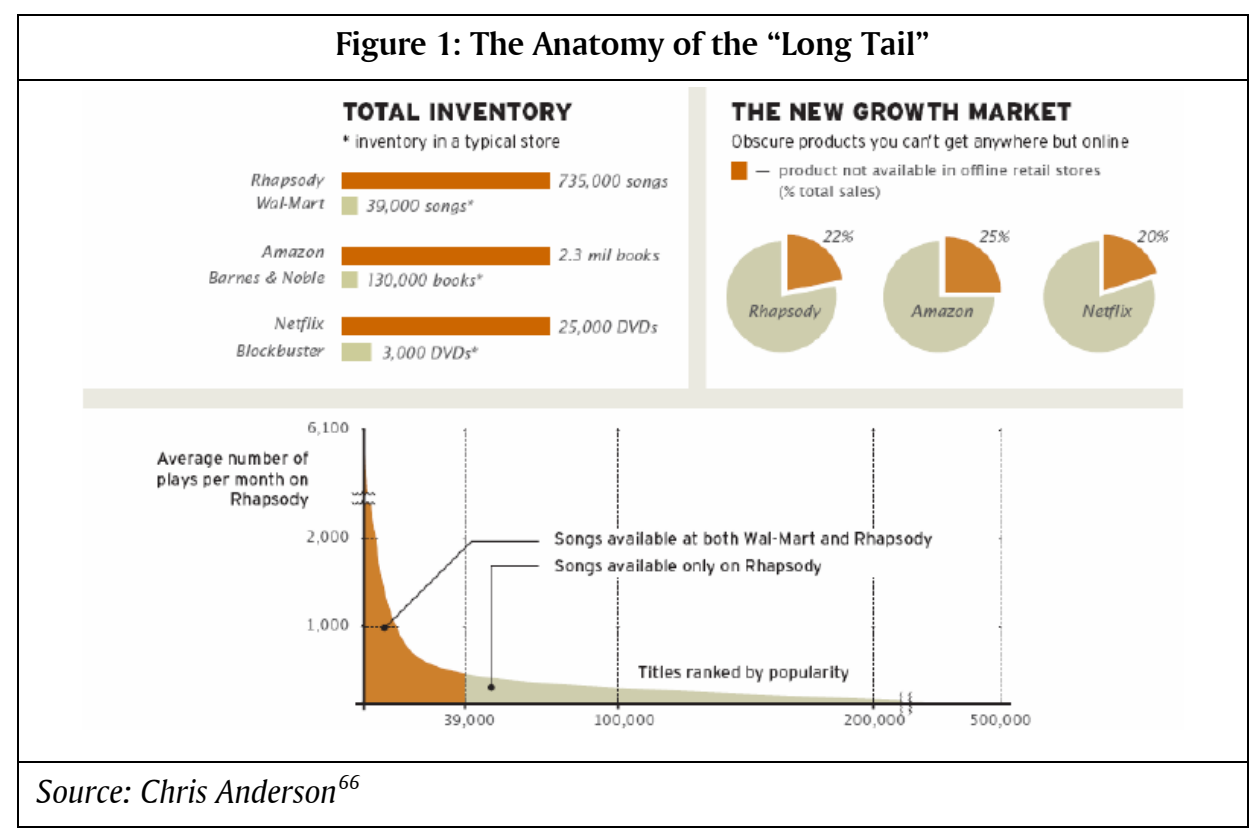

Yet, we show in the next paragraphs that the digital environment has given new dimensions to this underlying rule and has most importantly in our context, modified the rules of supply and demand for content, making a whole lot more of it available and accessible. This paradigm change has become known as "The Long Tail" theory and was coined by the editor of the Wired magazine, Chris Anderson in $2004,{ }^{67}$ although it builds upon substantiated prior and parallel research. ${ }^{68}$

Anderson's basic observation was that people online behave differently and do not go only for the "blockbusters" but for a manifold of niche products. Anderson tested this observation against raw data from the music and DVD 
markets off- and online. ${ }^{69}$ In its briefest form, the Long Tail theory holds that in digital markets: (i) supply and demand are not concentrated only on a small definite number of products (as in the offline world) and the tail of available variety is far longer than we realise; (ii) more importantly, the entire tail is now within reach economically (due to reasons we look at below); and (iii) all those niches, when aggregated make up a significant market.

The question then is what has made the Long Tail real in the digital environment?

On the supply side, the key factor determining whether a sales distribution has a long tail is the cost of inventory storage and distribution. Where the latter is insignificant, it becomes economically viable to sell relatively unpopular products. As already mentioned, this compares to the substantial storage and distribution costs of the offline world (or what Brynjolffson et. al., call "brick-and-mortar" world), ${ }^{70}$ where the shelf place (be it prime time in TV or a Christmas weekend at the cinema) is limited and so is the choice: A large conventional film rental, for instance, holds about 1'000 to 3'000 titles, while an online DVD rental like Netflix, operating from centralised warehouses, has about $30^{\prime} 000$. Where the products are only digitally available, the difference is even more striking: a large CD shop may hold about 40'000 titles, while an online music store will have about 20 times more (and constantly growing) number of titles (see Figure 1 above).

This by no means devalues the blockbusters or entirely abolishes the $80 / 20$ rule. $^{71}$ What it does however, is making the rest of the $80 \%$ of creative content (next to $20 \%$ of commercial hits) available and accessible from a consumer perspective, endorsing in parallel the economic reason for its further offering by businesses thus making altogether the Long Tail "thicker" and "longer".

On the demand side, the costs of searching and finding are crucial for the materialisation of the Long Tail (especially as variety becomes greater). On the one hand, this means the time invested in search; on the other hand, the efficiency of the search. The Internet is a vast complex nonlinear network that allows however to be searched through a single point of entry. Search engines help us locate content within the huge volume of dynamic information on the net, turning into linchpins of the Internet. ${ }^{72}$ The increasing availability of new tools, such as samples, feedbacks, recommendations enable users to find the desired 
products and even new products. ${ }^{73}$ As a result of this active search process, a constant generation of niche products/services occurs, which due to the new demand makes it economically attractive for the supply side as well and creates completely new markets. Furthermore, advanced search tools are not only given by the company that produces the goods or offers the services. Google PageRank, Amazon user review, Yahoo! Music ratings emerge as new information/orientation institutions. They are manifestations of a novel type of collective intelligence (the so-called, wisdom of the crowd), ${ }^{74}$ which creates effective filters of information that are essential in an ocean of data. A related key phenomenon, the so-called Web 2.0, which is characterised by interaction and user's contribution and not only facilitates search ${ }^{75}$ but leads to sharing experience and creating new content, will be looked into in the next section.

One must acknowledge at this stage that both the supply and demand side factors, as sketched above, are essentially dynamic. Firstly, because with the rapid advance in digital technology, the storage and distribution costs of products, and even the production expenses of physical goods (e.g., by printing on demand), are consistently falling; and secondly, because of the learning experience $^{76}$ and expansion of the network ${ }^{77}$ on the demand side.

This simple set of economic and technological drivers may have farreaching implications for businesses, consumers and the economy as a whole. ${ }^{78}$ As Anderson rather prophetically puts it, "[w] hen you can dramatically lower the costs of connecting supply and demand, it changes not just the numbers, but the entire nature of the market. This is not just a quantitative change, but a qualitative one, too. Bringing niches within reach reveals latent demand for noncommercial content. Then, as demand shifts toward the niches, the economics of providing them improve further, and so on, creating a positive feedback loop that will transform entire industries - and the culture - for decades to come ${ }^{\prime \prime}{ }^{79}$

An interesting implication in the concrete context of content and diversity of cultural expressions therein may stem from the possibility that in the digital environment content becomes accessible and usable long after its traditional viewing in cinema, TV, DVD rental or sale. ${ }^{80}$ The latter "one-off" purpose corresponds to the model of "pushing" content at a mass market of users. The digital environment allows however for individually "pulling" content and may 
thus change the value attached to cultural content. Put romantically, the value of the content transcends its mere "one-off" use and grants incentives for creating "good" content, be it original, avant-garde or traditional, which has implications for conventional (analogue) cultural policy measures.

\section{B. New Types of Content Production}

The spread of the network and its increasing density both in the sense of people online and billions of applications and contents, have led to the emergence of a new type of communication amongst users, new types of creativity and content production.

The digital environment reduces transaction costs involved in communicating and processing information about individual's preferences. Due to the decreased costs of identifying like-minded groups of individuals and the less costs of communicating and acting together, ${ }^{81}$ multiple virtual communities and social networks have emerged. ${ }^{82}$ Next to these new forms of social interaction and to the "conventional" use of the digital platform as a source of information and a communication facilitator, and much more critically for our present context, people online also create new content turning the web into a participative web (or what is often referred to as Web 2.0)..$^{83}$

Besides the intensified individual creation of content in the digital environment, ${ }^{84}$ a commons-based production of information, knowledge and entertainment emerges. ${ }^{85}$ "In all these communities of production, individuals band together, contributing small or large increments of their time and effort to produce things they care about. They do so for a wide range of reasons - from pleasure, through socially and psychologically rewarding experiences, to economic calculation...". ${ }^{86}$

Data on content creation, when available, is quite impressive. In countries such as Finland, Norway, Iceland, Portugal, Luxembourg, Hungary and Poland, in 2005, an average of one third of all Internet users aged 16-74 were engaged in content generation. Younger age groups (16-24) were even more active Internet content creators and show a participation of $60-70 \%$. The data from Asia and the US confirm this trend of ever increasing content contribution, especially where broadband is available and amongst the young ${ }^{87}$ Moreover, the 
mere fact that by the second quarter of 2006, 50 million blogs were created, new ones being added at a rate of two per second ${ }^{88}$ exemplifies the dynamism of the processes. Wikipedia is perhaps the most well-known (and much disputed) ${ }^{89}$ instance of commons-based creation: it is a multilingual, web-based, free content encyclopaedia project, written by volunteers, where the vast majority of articles can be edited by anyone with access to the Internet. Presently, Wikipedia has approximately 7.4 million articles in 253 languages $(1.8$ million in the English edition) and ranks among the top ten most-visited websites worldwide. ${ }^{90}$

It is only recently that the economic and social virtues of common ownership and production have begun to be explored. ${ }^{91}$ A recent report of the OECD does however acknowledge the enormous potential that user created content has and states that, "[t]he Internet as a new creative outlet has altered the economics of information production and led to the democratisation of media production and changes in the nature of communication and social relationships (sometimes referred to as the 'rise - or return - of the amateurs'). Changes in the way users produce, distribute, access and re-use information, knowledge and entertainment potentially gives rise to increased user autonomy, increased participation and increased diversity. These may result in lower entry barriers, distribution costs and user costs and greater diversity of works as digital shelf space is almost limitless". ${ }^{92}$

The new digital environment, characterised by abundance of content, empowerment of the user and multiple opportunities to re-use, mix, re-mix and share content, has led to increased economic importance of information, correspondingly magnifying the value of copyright law ${ }^{93}$ and expanding its reach. ${ }^{94}$ On the other hand, these developments have posed serious challenges to the existing copyright models. Since the latter are often too rigid to allow full realisation of the possibilities of the digital mode of content production and distribution (or indeed render them illegal), some new hybrid models of authors' rights protection have emerged. ${ }^{95} \mathrm{~A}$ most prominent such model is the Creative Commons (CC) licence, ${ }^{96}$ which allows managing and spreading of content under a "some rights reserved" mode. Under a cc-licence, the Creator/Licensor may shape her or his package of rights applying different conditions to the licensed work (attribution, noncommercial, no derivatives, share alike). ${ }^{97}$ People may thus use or distribute the work under the specified conditions, while the 
copyright of the creator remains intact. This new legal constructs have fed positively into the development of user-created content. ${ }^{98}$ "Increasingly search engines and UCC [user-created content] platforms allow for searches within Creative Commons-licensed photos, videos or other content allowing other users to use, build on them while creating new content. The rise of end-user licensing agreements (e.g., Second Life) which grant copyright to users for their content may also be a significant driver". ${ }^{99}$ To allow subsequent remix and creation, even major content providers, such as most notably Apple, called for an end to music copyright protection, ${ }^{100}$ and attempt to move away from Digital Rights Management (DRM) as the ultimate guarantee of authors' and producers' rights for digital media. ${ }^{101}$

\subsubsection{Repercussions for the Protection and Promotion of TCE}

It has not been the purpose of the preceding sections to convey the idea that markets (even new and emerging ones) will readily provide answers to all TCE-related questions, or that, traditional "culture is an underleveraged resource, and that we need to learn the sophisticated techniques for squeezing more money out of it". ${ }^{102}$

The above described technologies and transformed market mechanisms do however change the environment, where TCE are to be protected and promoted. These changes concern not only markets. Indeed, the digital environment has an impact on how artists and culture-makers express themselves, how they communicate with each other and with the public, how cultural content is presented and made accessible, how it is consumed. In short, it "affects the entire spectrum of culture production, distribution and presentation [...] [and] brings with it the promise of cultural renewal". ${ }^{103}$

While "the relationship between tradition, modernity and the market-place is not always perceived to be a happy one" ${ }^{104}$ (and often isn't), ${ }^{105}$ "[i]t is important too not to make artificial distinctions between traditional communities and the market-place, as many traditional communities engage in marketing aspects of their culture" ${ }^{106}$ Furthermore, although we do not underestimate the fact that many indigenous communities tend be to materially poor ${ }^{107}$ and that the digital divide is a reality, anecdotal and empirical evidence shows that indigenous peoples have been active users of the Internet for quite some time now (albeit certain communities reject it). They have been "using it to communicate amongst themselves and to others, to gain access to resources, to publish and access databases, and to provide alternative perspectives on issues that are not covered 
in mainstream media". ${ }^{108}$ It is even argued that many indigenous communities may overcome isolation through the Internet because it provides "an ideal medium for aboriginal communications"109 and that it may further prevent the erosion of aboriginal languages, whose maintenance feeds positively into reaffirmation of cultural traditions and a renewal of traditional relationships with the environment. ${ }^{110}$ Indeed, some argue that, "[t]he Internet is an ideal match for Aboriginal tribes, providing the necessary economy of scale to support electronic publishing for such small constituencies [...] because the Internet can support an admixture of audio, video, and text, transcending the print medium, it is ideally suited to the oral story-telling traditions of the Aboriginal Community". ${ }^{111}$ Software tools, including DRM, may enable authorised members of communities to better "define and control the rights, accessibility and reuse of their digital resources; uphold traditional laws pertaining to secret/sacred knowledge or objects; prevent the misuse of indigenous heritage in culturally inappropriate or insensitive ways; ensure proper attribution to the traditional owners; and enable indigenous communities to describe their resources in their own words". ${ }^{112}$ In addition, as we argued above, the emergence of softer, less rigid than the proprietary forms of IP protection, such as the Creative Commons licence, may prove particularly useful, allowing the custodians of TCE to shape their presentation reserving some rights of importance to the community, ${ }^{113}$ while leaving some in the public domain to be shared, remixed and reused. ${ }^{114}$ Such commons-based models may also correspond better to some indigenous forms of creation, where the author as a solitary figure is not central to the creative process and contribute to overcoming the binary code in the TCE discussions of either IP or public domain. ${ }^{115}$

Yet again, we do not deny that the processes of appropriation and misappropriation of TCE are facilitated in the digital environment. If we admit, however that, "[c]ulture is organic in nature and in order for it to survive, growth and development are necessary", ${ }^{116}$ the perspective changes: We must then put value upon creativity and the dynamic aspect of TCE. ${ }^{117}$ This transcends the preservation possibilities that digital technologies have allowed and means above all, protection and promotion of the indigenous communities. For, as Michael F. Brown notes, "if global cultural diversity is preserved on digital recording devices while the people who gave rise to this artistry and knowledge have disappeared, then efforts to preserve intangible property will be judged a failure ${ }^{\prime \prime}{ }^{118}$ 
Furthermore and we deem most crucially in our context, we cannon place the TCE discussions somehow in a parallel world totally unlinked to the modern, to this digital networked environment, whose reach will become only greater over time, and to its underlying issues, to its strives for innovation, access and cultural diversity. In this much broader sense of viewing the relationship "new technologies - TCE", the question is not so much whether indigenous communities use the Internet - a question that would normally lead to a discussion of TCE in development context and seek an instrumentalisation of ICT (information and communication technologies). ${ }^{119}$

We argue that the question is above all how the changed (and changing) $)^{120}$ digital environment influences all the complex institutions and processes that we partially outlined in the beginning of this paper and whether (and how) one could coherently and efficiently provide for the protection and promotion of TCE in this environment.

We hold that the new dynamism, diversity of content and empowerment of the users/communities may allow for designing a flexible and multi-faceted toolbox but also exasperate the interrelatedness of effects within the system, making regulatory decisions more precarious. In this sense, for instance, the granting of additional IP protection to forms of TCE is to be assessed as negative because it will have harmful repercussions within the larger complex system, among other things, reducing creativity and obstructing new cultural content production. ${ }^{121}$ The WIPO itself has admitted in this regard that certain amendments to the existing IPR regimes and the search for new forms are needed because of: (i) the preservation and safeguarding of intangible cultural heritage; (ii) the promotion of cultural diversity; and (iii) the promotion of creativity and innovation, including tradition-based one. ${ }^{122} \mathrm{New}$ initiatives, such as the projected Treaty on Access to Knowledge, ${ }^{123}$ which envisages some general limitations and exceptions to copyright (such as for educational or library institutions); special provisions regarding Internet Service Providers, DRM and the extension on the term of protection, as well as positive measures for the expansion and enhancement of the knowledge commons and the promotion of open standards, ${ }^{124}$ endorsing in effect maximum standards of IP protection, ${ }^{125}$ are a positive signal in this direction. 
Beyond IP, we argue that the sustainability of the digital environment will also become vital. In this context, developments, which one might characterise as purely technical and/or "foreign" to the system may seriously influence the TCE ecology as well. At the micro-level, digital sustainability, for instance, in the sense of ensuring that digitised formats, especially in the field of cultural heritage are interoperable, of high quality and future-proof, will certainly be important. ${ }^{126}$ In a broader context, the organisation of information by search engines, their precision, positioning and ultimately control, may be critical. ${ }^{127}$ We consider particularly important also all decisions and/or developments that influence the interoperability of networks, software and content, the control of the network, ${ }^{128}$ as well as the question of net neutrality. ${ }^{129}$

Finally, we suggest that the goal of TCE protection and promotion in the digital environment may be framed in the more overarching objective of ensuring sustainable access to cultural goods and sustainable production of culturally diverse content, ${ }^{130}$ which does not simply mean that everything is accessible in the romantic sense of the public domain ${ }^{131}$ but involves a complex balance between openness and discretion. ${ }^{132}$

\section{Conclusion}

It has been long acknowledged 133 that, "[t]he emergence of a global network of interconnected computers able to access, store, process, and transmit vast amounts of information in digital form has already altered our cultural landscape and, in the decades to come, [...] [will] transform many of our assumptions about communication, knowledge, invention, information, sovereignty, identity, and community". ${ }^{134}$ Through a couple of examples, we revealed that such changes are already discernible and their implications, while not fully explored, perceptible. It is thus essential that the impact of the digital environment is taken seriously into consideration when discussing TCE protection and promotion, because it is an inseparable part of this complex adaptive system and strongly influences its other elements, and may very well change both the objectives of TCE protection and the instruments for their achievement.

Until now, digital technologies have largely been perceived only in the rather narrow context of having implications for copyright, mostly with a negative connotation, or as instruments promoting development. This has been a hindrance to formulating a comprehensive positive approach for TCE protection 
in the digital networked environment. Such an approach grappling with all complex issues pertinent to TCE protection and promotion, will necessitate a large, multi-level, multi-faceted toolbox. It could be shaped along the WIPO model, which uses a combination of IP and sui generis options ${ }^{135}$ but will need to be supplemented by civil society efforts, ${ }^{136}$ education, capacitybuilding ${ }^{137}$ and involvement of grassroot organisations ${ }^{138}$ at national, regional and global level that raise the awareness for both TCE and the digital environment effects and opportunities and most likely, an adjustment of some IP rules. The latter model will admittedly be a little "messy"139 (comprising bottom-up and top-down approaches) but "compromise solutions are rarely elegant, yet they may be the best outcome when irreconcilable values collide". ${ }^{140}$

\section{Endnotes}

1 WIPO Intergovernmental Committee on Intellectual Property and Genetic Resources, Traditional Knowledge and Folklore (WIPO IGC), Consolidated Analysis of the Legal Protection of Traditional Cultural Expressions, WIPO/GRTKF/IC/5/3, 2 May 2003, Annex, at para. 4. For examples of appropriation and misappropriation of TCE, see ibid. Annex, at para. 94. See also Terri Janke, Minding Culture: Case Studies on Intellectual Property and Traditional Cultural Expressions, Geneva: WIPO, 2003.

2 Bellagio Declaration, formulated at the Rockefeller Conference: Cultural Agency/Cultural Authority: Politics and Poetics of Intellectual Property in the PostColonial Era, 11 March 1993, Bellagio, Italy (reproduced in James Boyle, Shamans, Software, and Spleens: Law and the Construction of the Information Society, Cambridge, MA: Harvard University Press, 1996, at pp. 196-200). See also Mihály Ficsor, The Law of Copyright and the Internet, Oxford: Oxford University Press, 2002, at paras 10.67 et. seq.

3 See further infra Section 2.

4 Committee on Economic, Social and Cultural Rights, General Comment No. 17: The Right of Everyone to Benefit from the Protection of the Moral and Material Interests Resulting from Any Scientific, Literary or Artistic Production of Which He Is the Author (Article 15(1)(c)), UN Doc. E/C.12/2005, 21 November 2005 (hereinafter General Comment No 17). On General Comment No 17, see Laurence R. Helfer, "Towards a Human Rights Framework for Intellectual Property" (2007) UC Davis Law Review, Vol. 40, pp. 971-1020; Peter K. Yu, "Reconceptualizing Intellectual Property Interests in a Human Rights Framework" (2007) UC Davis Law Review, Vol. 40, pp. 1039 1149; Hans Morten Haugen, "General Comment No 17 on 'Authors' Rights" (2007) The Journal of World Intellectual Property, Vol. 10:1, pp. 53-69. 
5 Article 15(1)(c) of the International Covenant on Economic, Social and Cultural Rights, UN Doc. A/6316 (1966), 993 UNTS 3, 16 December 1966, entered into force 3 January 1976.

6 Emphases added.

7 See in particular the contributions of Elizabeth Burns Coleman, Uma Suthersanen, Johanna Gibson, Wend Wendland, Martin Girsberger and Christoph Beat Graber. For a brief overview of the TCE pertinent issues, see Michael Blakeney, "Hans Christian Andersen and the Protection of Traditional Cultural Expressions" in Helle Porsdam (ed.), Copyright and Other Fairy Tales: Hans Christian and the Commodification of reativity, Cheltenham: Edward Elgar, 2006, pp. 108-128.

8 WIPO suggests a comprehensive definition of TCE, to which we subscribe in this paper: "Traditional cultural expressions" or "expressions of folklore" are any forms, whether tangible and intangible, in which traditional culture and knowledge are expressed, appear or are manifested, and comprise the following forms of expressions or combinations thereof:

i. verbal expressions, such as: stories, epics, legends, poetry, riddles and other narratives; words, signs, names, and symbols;

ii. musical expressions, such as songs and instrumental music;

iii. expressions by action, such as dances, plays, ceremonies, rituals and other performances; whether or not reduced to a material form; and

iv. tangible expressions, such as productions of art, in particular, drawings, designs, paintings (including bodypainting), carvings, sculptures, pottery, terracotta, mosaic, woodwork, metalware, jewelry, baskets, needlework, textiles, glassware, carpets, costumes; handicrafts; musical instruments; and architectural forms; which are: (aa) the products of creative intellectual activity, including individual and communal creativity; (bb) characteristic of a community's cultural and social identity and cultural heritage; and (cc) maintained, used or developed by such community, or by individuals having the right or responsibility to do so in accordance with the customary law and practices of that community. See WIPO IGC, The Protection of Traditional Cultural Expressions/Expressions of Folklore: Revised Objectives and Principles, WIPO/GRTKF/IC/8/4, 8 April 2005 (unaltered in WIPO/GRTKF/IC/9/4, WIPO/GRTKF/IC/10/4 and WIPO/GRTKF/IC/11/4(a)), Annex, at Article 1 (Subject Matter of Protection). For a detailed explanation of the notion of TCE, see WIPO IGC, supra note 1, Annex, at paras 48-67.

9 See Howard Morphy, Aboriginal Art, London: Phaidon, 1998, at pp. 67-100.

10 Michael F. Brown, "Can Culture Be Copyrighted?" (1998) Current Anthropology, Vol. 39:2, pp. 193-206, at p. 196. See also WIPO IGC, supra note 1, at para 9. 
11 Erica-Irene Daes, Study on the Protection of the Cultural and Intellectual Property of Indigenous Peoples, E/CN.4/Sub.2/1993/28, New York: United Nations Economic and Social Council, Commission on Human Rights, 1993, at para 21.

12 WIPO IGC, supra note 1, Annex, at para. 34. See also ibid. paras 42-43. On the major concerns of indigenous communities, see Terri Janke and Michael Frankel, Our Culture: Our Future: Report on Australian Indigenous Cultural and Intellectual Property Rights, prepared for the Australian Institute of Aboriginal and Torres Strait Islander Studies and the Aboriginal and Torres Strait Islander Commission, 1998, at pp. 19-42.

13 See Rosemary J. Coombe, "The Properties of Culture and the Possession of Identity: Postcolonial Struggle and the Legal Imagination" in Bruce Ziff and Pratima V. Rai (eds.), Borrowed Power: Essays on Cultural Appropriation, New Brunswick: Rutgers University Press, 1997, pp. 74-96. In addressing these diverse needs, WIPO has formulated a broad set of objectives that the TCE protection should aim at. They encompass: (i) recognition of value; (ii) promotion respect; (iii) meeting the actual needs of the communities; (iv) prevention of the misappropriation of TCE; (v) empowerment of communities; (vi) support of customary practices and community cooperation; (vii) contribution to safeguarding traditional cultures; (viii) encouraging community innovation and creativity; (ix) promotion of intellectual and artistic freedom, research and cultural exchange on equitable terms; $(x)$ contribution to cultural diversity; (xi) promotion of community development and legitimate trading activities; (xii) preclusion of unauthorised IP rights; and (xiii) enhancement of certainty, transparency and mutual confidence. See WIPO IGC, supra note 8, Annex, at p. 3.

14 On the history of IP and TCE protection, see WIPO IGC, supra note 1, Annex, at paras 68-90. See also Comparative Summary of Sui Generis Laws for the Protection of Traditional Cultural Expressions, WIPO/GRTKF//IC/5/INF/3, 28 April 2003.

15 Under IPR as a general category, one understands the rights granted to creators and inventors to control the use made of their productions. They are traditionally divided into two main branches: (i) "copyright and related (or neighbouring) rights" for literary and artistic works and (ii) "industrial property", which encompasses trademarks, patents, industrial designs, geographical indications, layout-designs of integrated circuits.

16 US Constitution, at Article I, Section 8, para. 8.

17 See e.g., Laurence R. Helfer, "Regime Shifting: The TRIPs Agreement and New Dynamics of International Intellectual Property Lawmaking" (2004) The Yale Journal of International Law, Vol. 29:1, pp. 1-83.

18 Rosemary J. Coombe, Steven Schnoor and Mohsen Ahmed, "Bearing Cultural Distinction: Informational Capitalism and New Expectations for Intellectual Property" (2007) UC Davis Law Review, Vol. 40, pp. 891-917, at p. 916, referring to Wend 
B. Wendland, "Intellectual Property and the Protection of Cultural Expressions: The World of the World Intellectual Property Organization" in F. Willem Grosheide and Jan J. Brinkof (eds.), Intellectual Property Law 2002, Antwerp: Intersentia, 2003, at pp. 101, 103.

19 Bellagio Declaration, supra note 2, at Discussion (footnotes omitted).

20 WIPO IGC, supra note 1, at paras 102-144. See also Christoph Beat Graber, "Can Modern Law Safeguard Archaic Cultural Expressions? Observations from a Legal Sociology Perspective" in Christoph Antons (ed.), Traditional Knowledge, Traditional Cultural Expressions and Intellectual Property Law in the Asia-Pacific Region, forthcoming 2007 (on file with the author).

21 Bellagio Declaration, supra note 2.

22 See e.g., General Comment No 17, at para. 35. For an interpretation, see Helfer, supra note 4, at pp. 997-1000.

23 See e.g., Wendy J. Gordon, "Intellectual Property" in Peter Can and Mark Tushnet (eds.), Oxford Handbook of Legal Studies, Oxford: Oxford University Press, 2003, Chapter 28, pp. 617-646; William M. Landes and Richard A. Posner, The Economic Structure of Intellectual Property Law, Cambridge, MA: Belknap Press of Harvard University, 2003, at pp. 11-123; Wendy J. Gordon and Robert G. Bone, "Copyright" in Boudewijn Bouckaert and Gerrit De Geest (eds.), Encyclopaedia of Law and Economics, Cheltenham: Edward Elgar Publishing, 2000, pp. 189-215.

24 Julie E. Cohen, "Creativity and Culture in Copyright Theory" (2007) UC Davis Law Review, Vol. 40, pp. 1151-1205, at p. 1193-1194. See also Bellagio Declaration, supra note 2, at Discussion.

25 US Supreme Court, Metro-Goldwyn-Mayer Studios, Inc., v. Grokster, Ltd., 125 S. Ct. 2764 (2005), referring to Sony Corp. of America v. Universal City Studios, Inc., 464 US 417 (1984), at 442. For a case note, see Urs Gasser and John G. Palfrey, Jr., "Catch-As-Catch-Can: A Case Note on Grokster", Berkman Center for Internet and Society Research Publication, October, 2005 and Tim Wu, "The Copyright Paradox Understanding Grokster", Supreme Court Review, 2006. See also Jane C. Ginsburg, "Copyright and Control Over New Technologies of Dissemination" (2001) Columbia Law Review, Vol. 101:7, pp. 1613 et. seq.; Douglas Lichtman and William M. Landes, "Indirect Liability for Copyright Infringement: An Economic Perspective" (2003) Harvard Journal of Law and Technology, Vol. 16:1, pp. 395-410.

26 See recently Cohen, supra note 24. See also Eben Moglen, "Anarchism Triumphant: Free Software and the Death of Copyright" in Niva Elkin-Koren and Neil Weinstock Netanel (eds.), The Commodification of Information, The Hague: Kluwer Law International, pp. 107-132; David Lange, "Reimagining the Public Domain" (2003) Law and Contemporary Problems, Vol. 66, pp. 463-483. 
27 Vaidhyanathan notes in this regard: "Copyright in recent years has certainly become too strong for its own good. It protects more content and outlaws more acts than ever before. It stifles creativity and hampers the discovery and sharing of culture and knowledge". See Siva Vaidhyanathan, "The Googlization of Everything and the Future of Copyright" (2007) UC Davis Law Review, Vol. 40, pp. 1207-1231, at p. 1210. Sharing this position, see also David Bollier, Silent Theft: The Private Plunder of Our Common Wealth, London: Routledge, 2003; Lawrence Lessig, Code and Other Laws of Cyberspace, New York: Basic Books, 1999; Lawrence Lessig, Free Culture: How Big Media Uses Technology and the Law to Lock Down Culture and Control Creativity, London: Penguin, 2004; Siva Vaidhyanathan, Copyrights and Copywrongs: The Rise of Intellectual Property and How It Threatens Creativity, New York: New York University Press, 2003.

28 World Conference on Human Rights, Vienna Declaration and Programme of Action, UN Doc.A/CONF.157/23, Part I, at para. 5.

29 Supra note 5.

30 General Comment No 17, at para. 28 (italicised in the original). See further paras 30-34 of the Comment. The Committee clarifies with specific regard to indigenous communities that, "States parties should adopt measures to ensure the effective protection of the interests of indigenous peoples relating to their productions, which are often expressions of their cultural heritage and traditional knowledge. In adopting measures to protect scientific, literary and artistic productions of indigenous peoples, States parties should take into account their preferences. Such protection might include the adoption of measures to recognize, register and protect the individual or collective authorship of indigenous peoples under national intellectual property rights regimes and should prevent the unauthorized use of scientific, literary and artistic productions of indigenous peoples by third parties". See General Comment No 17, at para. 32. For an analysis, see Christoph Beat Graber, "Traditional Cultural Expressions in a Matrix of Copyright, Cultural Diversity and Human Rights", NCCR Working Paper, 2007/08, forthcoming in Fiona Macmillan (ed.), New Directions in Copyright Law, Vol. 5, Cheltenham, UK: Edward Elgar, 2007.

31 General Comment No 17, at para. 4 (footnotes omitted).

32 Ibid. (footnotes omitted). For an overview of all TCE pertinent rights, see Graber, supra note 30 .

33 "In contrast to human rights, intellectual property rights are generally of a temporary nature, and can be revoked, licensed or assigned to someone else. While under most intellectual property systems, intellectual property rights, often with the exception of moral rights, may be allocated, limited in time and scope, traded, amended and even forfeited, human rights are timeless expressions of fundamental entitlements of the human person". See General Comment No 17, at para. 2. 
34 Helfer, supra note 4, at p. 980, referring to Robert O. Keohane and Joseph S. Nye, Jr., "The Club Model of Multilateral Cooperation and Problems of Democratic Legitimacy" in Roger B. Porter et. el. (eds.) Efficiency, Equity, and Legitimacy: The Multilateral Trading System at the Millennium, pp. 264 et. seq., at p. 266.

35 UNESCO, Convention on the Protection and Promotion of the Diversity of Cultural Expressions, adopted at the 33rd Session of the General Conference of UNESCO, 20 October 2005, entered into force 18 March 2007 (hereinafter UNESCO Convention on Cultural Diversity). On the negotiating history, see Ivan Bernier, "A UNESCO International Convention on Cultural Diversity" in Christoph Beat Graber, Michael Girsberger and Mira Nenova (eds.), Free Trade versus Cultural Diversity: WTO Negotiations in the Field of Audiovisual Services, Zurich: Schulthess, pp. 65-76.

36 See UNESCO Convention on Cultural Diversity, at Article 1, points (a), (b) and (g) respectively.

37 "Cultural diversity" refers to the manifold ways in which the cultures of groups and societies find expression. These expressions are passed on within and among groups and societies. Cultural diversity is made manifest not only through the varied ways in which the cultural heritage of humanity is expressed, augmented and transmitted through the variety of cultural expressions, but also through diverse modes of artistic creation, production dissemination, distribution and enjoyment, whatever the means and technologies used. UNESCO Convention on Cultural Diversity, at Article 4(1).

38 Article 6(1) defines the core right of the State parties to "adopt measures aimed at protecting and promoting the diversity of cultural expressions within its territory". TCE are mentioned only in a cursory manner in the Convention in para. 13. Para. 15, Article 2 and Article 7(1)(a) refer further to indigenous peoples. See also Nicole Aylwin and Rosemary J. Coombe, "Cultural Pluralism Protects Traditional Knowledge", 2006, available at http://www.wacc.org.uk/wacc/publications/media_ development/2006_3/cultural_pluralism_protects_traditional_knowledge.

39 IPRs are mentioned only in the Preamble of the Convention.

40 Article 20(1) states that "Parties recognize that they shall perform in good faith their obligations under this Convention and all other treaties to which they are parties. Accordingly, without subordinating this Convention to any other treaty, (a) they shall foster mutual supportiveness between this Convention and the other treaties to which they are parties; an (b) when interpreting and applying the other treaties to which they are parties or when entering into other international obligations, Parties shall take into account the relevant provisions of this Convention". Article 20(2) adds on the other hand that, "Nothing in this Convention shall be interpreted as modifying rights and obligations of the Parties under any other treaties to which they are parties". See Christoph Beat Graber, "The New UNESCO Convention on Cultural Diversity: A Counterbalance to the WTO" (2006) Journal of International Economic Law, Vol. 9, No 3, pp. 553-574 
41 See Articles 5-10 of the UNESCO Convention on Cultural Diversity. For a critique of the lack of binding obligations, see Keith Acheson and Christopher Maule, "Convention on Cultural Diversity" (2004) Journal of Cultural Economics, Vol. 28, pp. 243-256.

42 See in particular the contributions of Martin Girsberger and Christoph Beat Graber.

43 Michael F. Brown, "Heritage Trouble: Recent Work on the Protection of Intangible Cultural Property" (2005) International Journal of Cultural Property, Vol. 12, pp. 40-61, at p. 41 .

44 On non-rivalry, see Patrick McNutt, "Public Goods and Club Goods" Boudewijn Bouckaert and Gerrit De Geest (eds.), Encyclopaedia of Law and Economics, Cheltenham: Edward Elgar Publishing, 2000, pp. 927-951, at pp. 928 et. seq.

45 "Most conspicuously, it can reside in an infinite number of places simultaneously. The homelessness of information undermines the distinction between real and counterfeit, just as it weakens the bounds that tie units of information together in meaningful systems". See Brown, "Heritage Trouble", supra note 43, at pp. 41-42.

46 Brown, ibid. at p. 42.

47 Generally, on complex adaptive systems, see e.g., Paul Cilliers, Complexity and Postmodernism: Understanding Complex Systems, London: Routledge, 1998; Yaneer Bar-Yam, Dynamics of Complex Systems, Boulder, CO: Westview Press, 2003. On the application of the complex system theory to communications, see P.H. Longstaff, The Communications Toolkit, Cambridge, MA: MIT Press, 2002, at pp. 16 et. seq.; P.H. Longstaff, "Competition in the Communications Sector: Can Predictability Be Regulated", Program on Information Resources Policy, Harvard University, April 2003, at pp. 14 et. seq. On networks, see Mark Newman, AlbertLászló Barabási, Duncan J. Watts (eds.), The Structure and Dynamics of Networks, Princeton, NJ: Princeton University Press, 2006.

48 Milton L. Mueller, "Digital Convergence and its Consequences: A Report on the Digital Convergence and Market Structures", 1999, available at http://dcc.syr.edu/ miscarticles/rp1.pdf. Gordon Moore of Intel postulated in 1965 that the transistor density on a single integrated circuit microchip would double approximately every eighteen months. This rule showing the incredible pace of technological advance became known as Moore's Law and (as unlikely as it may seem) is still valid. On Moore's Law, see e.g., Rob Frieden, Managing the Internet-Driven Change in International Telecommunications, Boston/London: Artech House, 2001, at pp. 17 et. seq.

49 The concept was originally developed at Standard Telephones and Cable Ltd., England. For more on the development of optical fibre technology, see David Gillies and Roger Marshall, Telecommunications Law, Vol. 1, 2nd edition, London: Butterworths LexisNexis, 2003, at p. 19. 
50 Metcalfe's Law holds that the potential value of network increases by square of number of nodes, while the Fibre Law holds that capacity doubles every nine months. See e.g., Chris Marsden, Jonathan Cave, Edward Nason, Andrew Parkinson, Colin Blackman and Jason Rutter, Assessing Indirect Impacts of the EC Proposals for Video Regulation, Report Prepared for the UK Office of Communications, RAND Europe, 2006, at pp. 72 et. seq. Currently, almost all networks (in developed and even in developing countries) have become IP-based. See OECD, Information Technology Outlook 2006, Paris: OECD, 2007.

51 For a brief history of the Internet, see the Internet Society's account, available at http://www.isoc.org/ internet/history/brief.shtml.

52 For a precise explanation on how the world wide web functions, see Tim Berners-Lee et. al., Architecture of the World Wide Web, Vol. 1, W3C Recommendation, 15 December 2004, available at http://www.w3.org/TR/webarch/. For an overview of developments of the www, see Jeremy G. Butler, "The Internet and the World Wide Web" in Dan Harries (ed.), The New Media Book, London: British Film Institute Publishing, pp. 40-51.

53 For excellent examples, see OECD, Digital Broadband Content: Mobile Content. New Content for New Platforms, DST/ICCP/IE(2004) 14/Final, 3 May 2005; OECD, Digital Broadband Content: The Online Computer and Video Game Industry, DST/ICCP/IE(2004)13/Final, 12 May 2005; OECD, Digital Broadband Content: Scientific Publishing, DST/ICCP/IE(2004)11/Final, 2 September 2005; OECD, Digital Broadband Content: Music, DST/ICCP/IE(2004)12/Final, 13 December 2005.

54 Edwin Horlings, Chris Marsden, Constantijn van Oranje and Maarten Botterman, Contribution to Impact Assessment of the Revision of the Television without Frontiers Directive, RAND Europe, TR-334-EC DG, 1 November 2005, at p. 6. See also e.g., PEW Internet and American Life Project, More Online, Doing More, February 2001 and Internet Penetration and Impact, April 2006; both available at http://www.pewinternet.org/.

55 Technological developments stemming from the Internet technology like IPTV (Internet Protocol television) or video-on-demand will also be taken into consideration.

56 Since technologies are in a constant state of flux, as a rule-of-thumb, any technological advance that has a bearing upon the means and conditions of communication and information distribution across the different layers (network/ logic/applications/content), will be relevant to the present discussion of TCE and new technologies.

57 See Manuel Castells, The Information Age: Economy, Society and Culture, Vol. 1: The Rise of the Network Society, 2nd edition, Oxford: Blackwell, 2000. For a critique, see Nicholas Garnham, Information Society Theory as Ideology: A Critique (2001) Studies in Communications Sciences, Vol. 1, pp. 129-166. For an overview of the theories, see Frank Webster, Theories of Information Society, London: Routledge, 1995; Frank Webster (ed.), The Information Society Reader, London: Routledge, 2004. 
58 Stylianos Papathanassopoulos, European Television in the Digital Age", Cambridge: Polity, 2002, at p. 14.

59 European Commission, Fifth Report on the Application of Directive 89/552/EEC "Television without Frontiers", $\operatorname{COM}(2006) 49$ final, 10 February 2006, referring to the European Audiovisual Observatory, 2004 Yearbook.

60 Papathanassopoulos, at pp. 17-18.

61 Papathanassopoulos, at pp. 18-19, referring to Jay G. Blumler, "Vulnerable Values at Stake" in Jay G. Blumler (ed.), Television and the Public Interest: Vulnerable Values in Western European Broadcasting, London: Sage, 1992, pp. 22-24; Yves Achile and Bernard Miège, "The Limits of Adaptation Strategies of European Public Service Television" (1994) Media, Culture and Society, Vol. 16, pp. 31-46.

62 Papathanassopoulos, at p. 19, referring to Denis McQuail, "Commercialisation and Beyond" in Denis McQuail and Karen Siune (eds.), Media Policy: Convergence, Concentration and Commerce, London: Sage, 1998, pp. 107-127, at pp. $119-120$ and Laurie Ouilette and Justin Lewis, "Moving Beyond the 'Vast Wasteland': Cultural Policy and Television in the United States" (2000) Television and New Media, Vol. 1, No 1, pp. 95-115, at p. 96. On the "multi-channel paradox", whereby despite the diversity of channels, there is no actual diversity of content, see Mónica Ariño, "Competition Law and Pluralism in European Digital Broadcasting: Addressing the Gaps" (2004) Communications and Strategies, No 54, pp. 97-128, at pp. 98 et. seq.

63 For a critique of the cultural industries and on the homogeneity of content, see Christoph Beat Graber, Handel und Kultur im Audiovisionsrecht der WTO. Völkerrechtliche, ökonomische und kulturpolitische Grundlagen einer globalen Medienordnung, Berne: Staempfli, 2003, at pp. 18 et. seq. For counter arguments, see Gaetano Romano, "Technologische, wirtschaftliche und kulturelle Entwicklungen der audiovisuellen Medienmärkte in den letzten Jahren" in Graber, Girsberger and Nenova, supra note 35, pp. 1-13, at pp. 4 et. seq.

64 "For too long we've been suffering the tyranny of lowest-common-denominator fare, subjected to brain-dead summer blockbusters and manufactured pop. Why? Economics. Many of our assumptions about popular taste are actually artifacts of poor supply-and-demand matching - a market response to inefficient distribution". Chris Anderson, The Long Tail: Why the Future of Business Is Selling Less of More, New York: Hyperion, 2006, at p. 16.

65 See generally Carl Shapiro and Hal R. Varian, Information Rules, Cambridge, MA: Harvard Business School Press, 1998. See with regard to the world wide web, F. Faloutsos, P. Faloutsos and C. Faloutsos, "On Power-Law Relationships of the Internet Topology" in Mark Newman, Albert-László Barabási, Duncan J. Watts (eds.), The Structure and Dynamics of Networks, Princeton, NJ: Princeton University Press, 2006, pp. 195-206. 
66 Chris Anderson, The Long Tail, Manifesto, 10:1, 14 December 2004, available at http://www.changethis.com/10.LongTail.

67 Chris Anderson, "The Long Tail", Wired, Issue 12.10, October 2004. It became later in 2006 a more comprehensive book, see supra note 64 .

68 See in particular Erik Brynjolfsson, Yu Hu and Michael D. Smith, "Consumer Surplus in the Digital Economy: Estimating the Value of Increased Product Variety at Online Booksellers" (2003) MIT Sloan Working Paper No 4305-03; Erik Brynjolfsson, Yu Hu and Michael D. Smith, "From Niches to Riches: The Anatomy of the Long Tail" (2006) Sloan Management Review, Vol. 47:4, pp. 67-71; Erik Brynjolfsson, Yu Hu and Duncan Simester, "Goodbye Pareto Principle, Hello Long Tail: the Effect of Search Costs on the Concentration of Product Sales", February 2007, available at SSRN: http://ssrn.com/abstract $=953587$.

69 Rhapsody and Netflix respectively. For an extensive analysis of online book markets, see Brynjolfsson, Hu and Smith, "Consumer Surplus in the Digital Economy", ibid.

70 Brynjolfsson, Hu and Smith, "From Niches to Riches", supra note 67.

71 The $80 / 20$ is only slightly challenged (at least at this point of time). Brynjolfsson et. al., observe obscure book titles, for instance, which were not even stocked by typical conventional bookstores because of their low sales, accounted for about $40 \%$ of Amazon.com's book sales revenue in year 2000, instead of the normally expected $20 \%$. See Brynjolfsson, Hu and Smith, "Consumer Surplus in the Digital Economy", supra note 67.

72 James Grimmelmann, "The Structure of Search Engine Law", New York Law School Research Paper Series 06/07, No 23. at p. 2, referring to John Battelle, The Search: How Google and Its Rivals Rewrote the Rules of Business and Transformed Our Culture, New York: Portfolio, 2005; David Vise and Mark Malseed, The Google Story: Inside the Hottest Business, Media, and Technology Success of Our Time, Delta, 2006. A survey shows that only the act of sending or reading email outranks search engine queries as an online activity (PEW Internet and American Life Project, Search Engines, 2002, available at http://www.pewinternet.org//).

73 Brynjolfssonn et. al., analyzed consumer purchase data collected from a retailing company that has both an Internet channel and a catalogue channel. The company sells exactly the same product selection in both channels with the same pricing and shipping policies. However, because of search, browsing, and recommendation tools that are unique to the Internet channel, product sales are significantly more evenly distributed on the Internet than through the catalogue channel where sales are more concentrated on best-selling products. For the catalogue channel, the top $20 \%$ of products generate just over $80 \%$ of this company's sales, mirroring the $80 / 20$ rule. However, at the company's Internet channel, the same top $20 \%$ products generate barely $70 \%$ of sales. Since the same products are available in both channels at this retailer, this shows that the demand side drivers of the Long Tail phenomenon can 
operate independently of the supply side drivers such as virtual shelf space. See Brynjolfsson, Hu and Smith, "From Niches to Riches", supra note 67. Experience with P2P networks shows equally that the initial experience of users focusing on hits is supplanted rapidly by more varied choice of content, and by adaptation and "mashing" of content into new forms. See Marsden et. al., supra note 50, at p. 23.

74 See James Surowiecki, The Wisdom of Crowds: Why the Many Are Smarter Than the Few and How Collective Wisdom Shapes Business, Economies, and Nations, New York: Doubleday, 2003.

75 In the context of search, "tagging" may be identified as an important Web 2.0 effect. Tagging, which is basically a process of creating labels for online content by attaching a keyword to a piece of information (e.g. a picture, Article or video) is "a kind of next-stage search phenomenon", whereby online searching is advanced and personalised and digital material is organised in a tailored manner on top of existing formally defined classification schemes. See PEW Internet and American Life Project, Tagging, January 2007, available at http://www.pewinternet.org/.

76 See e.g., PEW Internet and American Life Project, The Broadband Difference: How Online American's Behaviour Changes with High-Speed Internet Communications at Home, 2002, available at http://www.pewinternet.org/.

77 On positive network effects, see e.g., Shapiro and Varian, supra note 65, at pp. 173-225.

78 Brynjolfsson, Hu and Smith, "From Niches to Riches", supra note 67, at p. 1.

79 Anderson, supra note 64, at p. 26. See also Brynjolfsson, Hu and Smith, ibid. at pp. 6-8.

80 Marsden et. al., supra note 50, at pp. 22-23.

81 Urs Gasser, "Social Structures in Cyberspace: The Design and Function of Digital Institutions", Discussion Paper presented at the 9th Annual Conference of the International Society for New Institutional Economics: The Institutions of Market Exchange", 22-24 September 2005, Barcelona, at para. 1. See also Marshall Van Alstyne and Erik Brynjolfsson, "Global Village or Cyber-Balkans? Modeling and Measuring the Integration of Electronic Communities" (2004) Management Science.

82 See most prominently http://www.myspace.com/ or http://www.facebook.com/. To reveal the sheer dynamism of these networks, O'Reilly Radar shows that during the first quarter of 2006, 280000 new users signed up each day to MySpace and it had the second most Internet traffic. See John Musser with Tim O'Reilly, Web 2.0: Principles and Best practices, O'Reilly Radar, November 2006, at p. 4.

83 Web 2.0 is a phrase coined by O'Reilly Media (http://www.oreilly.com/) in 2004. Proponents of the Web 2.0 concept say that it differs from early Web development (labelled Web 1.0) in that it moves away from static websites, the use of search engines and surfing from one website to the next, towards a more dynamic and interactive World Wide Web. See Tim O'Reilly, "What Is Web2.0?: Design Patterns and Business Models for the Next Generation Software", 30 September 2005, 
available at http://www.oreillynet.com/pub/a/oreilly/tim/news/2005/09/30/what-isweb- 20.html. See also John Musser with Tim O'Reilly, ibid.; OECD, Participative Web: User-Created Content, DSTI/ICCP/IE(2006)7/FINAL, 12 April 2007.

84 See e.g., Tom O'Regan and Ben Goldsmith, "Emerging Global Ecologies of Production" in Dan Harries (ed.), The New Media Book, London: British Film Institute Publishing, pp. 92-105.

85 The content covers a wide range of types. OECD identifies eight categories: (i) text, novel and poetry; (ii) photo and images; (iii) music and audio; (iv) video and film; (v) citizen journalism; (vi) educational content; (vii) mobile content; and (viii) virtual content. See OECD, Participative Web, supra note 82, at p. 15. For examples, see pp. 16-18.

86 Yochai Benkler, "Freedom in the Commons: Towards a Political Economy of Information" (2003) Duke Law Review, Vol. 52, pp. 1245-1276, at p. 1261.

87 OECD, Participative Web, supra note 82, at pp. 9-12. See also PEW Internet and American Life Project, Content Creation Online, 29 February 2004, available at http://www.pewinternet.org/.

88 See John Musser with Tim O'Reilly, supra note 81.

89 As Wikipedia itself notes: "Wikipedia appeals to the authority of peer-reviewed publications rather than the personal authority of experts. Wikipedia does not require that its contributors give their legal names or provide other information to establish their identity. Although some contributors are authorities in their field, Wikipedia requires that even their contributions be supported by published sources. Wikipedia tries to address the problem of systemic bias, and to deal with zealous editors who seek to influence the presentation of an Article in a biased way, by insisting on a neutral point of view. [...] Some studies suggest that Wikipedia provides a good starting point for research, but sometimes suffers from significant omissions and inaccuracies. On the other hand, an investigation by Nature comparing Wikipedia to the Encyclopaedia Britannica suggested a near similar level of accuracy in terms of its natural science articles. Encyclopaedia Britannica Inc., disagreed and described this study as "fatally flawed", to which Nature later responded, stating that its study was perfectly neutral. Other studies have concluded that Wikipedia's coverage of history is significantly broader and deeper than that of Encarta, while being just as accurate, and that obvious vandalism is usually reverted quickly. [...] In February 2007, an Article in The Harvard Crimson newspaper reported that some of the professors at Harvard University do include Wikipedia in their syllabi, but that there is a split in their perception of using Wikipedia. See http://en.wikipedia.org/wiki/Wikipedia\#_note-0 (footnotes omitted).

90 See http://en.wikipedia.org/wiki/Wikipedia\#_note-0 and all the references listed there. See also a very interesting contribution George Bragues, "Wiki-Philosophizing in a Marketplace of Ideas: Evaluating Wikipedia's Entries on Seven Great Minds", April 2007, available at http://ssrn.com/abstract=978177. 
91 Gordon, supra note 23, at p. 624, referring to Yochai Benkler, "Coase's Penguin, or Linux and the Nature of the Firm" (2002) Yale Law Journal, Vol. 112, pp. 369-446; Carol M. Rose, "The Several Futures of Property: Of Cyberspace and Folk Tales, Emission Trades and Ecosystems" (1998) Minnesota Law Review, Vol. 83, pp. 129-182. See also Yochai Benkler, The Wealth of Networks: How Social Production Transforms Markets and Freedom. New Haven: Yale University Press, 2006. Jack Balkin argues in the social context that a democratic culture is a participatory culture and thus stresses the need for facilitating participation. See Jack M. Balkin, "Digital Speech and Democratic Culture: A Theory of Freedom of Expression for the Information Society" (2004) New York University Law Review, Vol. 79:1, pp. 1-58, at p. 35.

92 OECD, Participative Web, supra note 82, at p. 5. The OECD Report elaborates further that, "[ $t]$ hese changes imply a shift away from simple passive consumption of broadcasting and other mass distribution models ('couch potatoes') to more active choosing, interacting and actually creating of content and a shift to a participatory 'culture'. Technological change empowers individuals to 'tell their stories', to produce cultural goods such as music and to transform the information and media content environment surrounding them. Users may derive a higher value from this content consumption as the content may be more personalised as users have a greater control over this on-demand content". See ibid. at p. 35, referring to Lessig, supra note 27; William W. Fisher III, Promises to Keep: Technology, Law, and the Future of Entertainment, Stanford: Stanford University Press, 2004; William W. Fisher III, speech at the OECD Italian government Conference on The Future Digital Economy Digital Content - Creation, Distribution and Access, 30- 31 January 2006, Rome, available at www.oecd.org/dataoecd/16/44/36138608.pdf; OECD, The Future Digital Economy: Digital Content Creation, Distribution and Access, 30-31 January 2006, Rome; and Benkler, supra note 90.

93 Brown, "Heritage Trouble", supra note 43, at p. 44. See also Julie E. Cohen, "Pervasively Distributed Copyright Enforcement" (2006) Georgetown Law Journal, Vol. 95, pp. 1-48.

94 Lawrence Lessig, "(Re)creativity: How Creativity Lives" in Helle Porsdam (ed.), Copyright and Other Fairy Tales: Hans Christian and the Commodification of Creativity, Cheltenham: Edward Elgar, 2006, pp. 15-22, at p. 19.

95 On copyright and user-created content, see OECD, Participative Web, supra note 82, at pp. 44-52. See also Urs Gasser and Silke Ernst, "From Shakespeare to DJ Danger Mouse: A Quick Look at Copyright and User Creativity in the Digital Age", Berkman Center for Internet and Society Research Publication No 2006-05, June 2006.

96 See http://creativecommons.org/. There are also some under types of licences designed by the Creative Commons, such as public domain, developing nations, sampling, founder's copyright, GNU, Wiki and music sharing. The "developing nations" licence allows, for instance, a wide range of royalty-free uses of a work in developing nations, while retaining full copyright in the developed world. 
97 See http://creativecommons.org/about/licenses/meet-the-licenses.

98 OECD, Participative Web, supra note 82, at p. 14.

99 OECD, ibid. (footnote omitted).

100 John Markoff, "Jobs Calles for End to Music Copy Protection", The New York Times, 7 February 2007.

101 "Apple Unveils Higher Quality DRM-Free Music on the iTunes-Store: DRM-Free Songs from EMI Available on iTunes for \$1.29 in May", Apple Press Release, 2 April 2007.

102 David Bollier, "Globalization and Diversity, UNESCO and Cultural Policymaking: Imperatives for US Arts and Culture Practitioners and Organizations", speech at the Smithsonian Institution, Washington, DC, 11 January 2005.

103 Netherlands Council for Culture, From ICT to E-Culture: Advisory Report on the Digitalisation of Culture and the Implications for Cultural Policy, submitted to the State Secretary for Education, Culture and Science, June 2003 (English edition, August 2004), at p. 8. See also PEW Internet and American Life Project, Artists, Musicians and the Internet, December 2004, available at http://www.pewinternet.org/.

104 WIPO IGC, supra note 1, Annex, at para. 13.

105 Tyler Cowen is one of the very few, who insists in his book "Creative Destruction" that global monopolies and imported technologies have also led to promoting local creativity by generating new markets for innovative, highquality artistic productions. See Tyler Cowen, Creative Destruction: How Globalization Is Changing the World's Cultures, Princeton: Princeton University Press, 2002 and Cowen, In Praise of Commercial Culture, Cambridge, MA: Harvard University Press, 1998, in particular at pp. 15-43.

106 WIPO IGC, supra note 1, Annex, at para. 14. See also the contribution to this volume by Miriam Sahlfeld.

107 See Graham Dutfield, "Promoting Local Innovation as a Development Strategy" (2006) Innovations: Technology, Governance, Globalization, Vol. 1:3, pp. 67-77, at pp. 72-73, referring to the work of Anil K. Gupta, "From Sink to Source: The Honey Bee Network Documents Indigenous Knowledge and Innovations in India" (2006) Innovations: Technology, Governance, Globalization, Vol. 1:3, pp. 49-66.

108 Rosemary J. Coombe, "Preserving Cultural Diversity through the Preservation of Biological Diversity: Indigenous Peoples, Local Communities, and the Role of Digital Technologies" in Fiona Miller et. al., (eds.), The Gender of Genetic Futures, NNEWH Working Paper Series, September 2000, pp. 132-160, at p. 147.

109 Coombe, ibid. at p. 148.

110 Coombe, ibid. at pp. 147-148, referring to L. Maffi and T. Skutnabb-Kangas, "Linguistic Diversity and the "Curse of Babel"", United Nations Environment Programme, Cultural and Spiritual Values of Biodiversity, London: Intermediate 
Technology Publications, 2000. See also recently Ethan Zuckerman, "The Survival of Languages in a Digital Age", 16 May 2007, available at http://www. ethanzuckerman.com/blog/? $p=1426$.

111 Barry Zellen, "Surf's Up!: NWT's Indigenous Communities Await a Tidal Wave of Electronic Information" (1998) Cultural Survival Quarterly, 21:4, as referred to by Coombe, ibid. at p. 148.

112 WIPO IGC, supra note 1, Annex, at para. 245, referring inter alia to Jane Hunter, Bevan Koopman and Jane Sledge, Software Tools for Indigenous Knowledge Management", September 2002, available at http://www.archimuse.com/mw2003/ papers/hunter/ hunter.html.

113 Kansa et. al., find the creative commons licence appropriate for TK/TCE protection and suggest ways in which it could be better moulded to correspond to the needs of indigenous communities. See Eric C. Kansa, Jason Schultz and Ahrash N. Bissell, "Protecting Traditional Knowledge and Expanding Access to Scientific Data: Juxtaposing Intellectual Property Agendas via a 'Some Rights Reserved' Model" (2005) International Journal of Cultural Property, Vol. 12, pp. 285- 314.

114 Lawrence Lessig offers some examples of CC spread "in cultures far from our headquarters in San Francisco". The first example comes from Brazil, at the site Overmundo (http://www.overmundo.com.br). The latter is a collaborative website designed to spread Brazilian culture. Its distinction is that both its content and design are generated by users and everything made available on the site under a CC license. The Overmundo tools give users the capacity to rate the quality of contributed content. The community has built a "cultural database", with thousands of people sharing and making content available broadly. In less than 7 months, there have been more than 7,000 contributors from all over Brazil. The site's traffic is growing by $20 \%$ per month, and there are more than 400,000 references to it recorded by Google. A second example comes from South Africa. ccMixter South Africa (http://www.ccmixter.co.za) is leading a unique cultural remixing competition, drawing upon the work of creators from both Brazil and South Africa. The competition is part of the "culturelivre" project, which is a joint effort of Creative Commons in Brazil and South Africa. To find samples for the competition, ccSA invited some of the most important custodians of musical heritage in South Africa including the International Library of African Music (ILAM) - to produce short riffs using traditional African instruments. Among these instruments are the Mutumba drums, which are generally inaccessible on the Internet today. These drums were originally from Zimbabwe and used to accompany spiritual ceremonies that include dancing, singing, clapping and playing the mbira thumb piano. Young musicians entering the competition can remix these traditional sounds, and in the process, develop an understanding of the roots of music in both cultures. See Lawrence Lessig, cc letter, 16 November 2006, available at http://creativecommons.org/ weblog/entry/6155.

115 Kansa et. al., supra note 112. 
116 WIPO IGC, supra note 1, at para. 8.

117 Elizabeth Burns Coleman argues in this volume that TCE may indeed be perceived as more dynamic than modern cultural production.

118 Brown, "Heritage Trouble", supra note 43, at p. 54. See also Graham Dutfield, "Protecting and Revitalising Traditional Ecological Knowledge: Intellectual Property Rights and Community Knowledge Databases in India" in Michael Blakeney (ed.), Intellectual Property Aspects of Ethnobiology, Perspectives on Intellectual Property, Vol. 6, London: Sweet \& Maxwell, 1999, pp. 103-122, at p. 109.

119 Even broader fora, like the World Summit on the Information Society (WSIS), engage above all in this instrumentalisation aspect. See WSIS, Declaration of Principles, WSIS-03/Geneva/Doc/4-E, 12 December 2003; WSIS, Plan of Action, WSIS03/Geneva/Doc/5-E, 12 December 2003; WSIS, Tunis Commitment, WSIS05/Tunis/Doc/7-E, 18 November 2005; WSIS, Tunis Agenda for the Information Society, WSIS-05/Tunis/Doc,6(Rev.1)-E, 18 November 2005.

120 Forecasts show, for instance, that by 2020 a global, low-cost network will be available to most people around the world. In a similar vein but less in the sense of prediction, the EU Member States will complete the transition to digital signal by 2010-2014 and analogue broadcasting will cease to exist as such. See respectively, PEW Internet and American Life Project, The Future of the Internet II, 24 September 2006, at pp. i-ii and Horlings et. al., supra note 54, at p. 13.

121 See e.g., Gasser and Ernst, supra note 94.

122 WIPO IGC, supra note 1, at para. 8. The civil society has already formulated its call for less stringent IPRs in the Declaration on the Future of the WIPO (12 October 2004, at http://www.futureofwipo.org) adopted prior to the discussion of the WIPO Development Agenda at the 31 st session of the WIPO General Assembly. Stating that, "[h]umanity faces a global crisis in the governance of knowledge, technology and culture", the drafters of the Geneva Declaration, sought a new balance of the social and economic costs of IPR, a reform of the existing IPR regimes and an innovative approach using non-proprietary systems, such as "Wikipedia, the Creative Commons, GNU Linux and other free and open software projects, as well as distance education tools and medical research tools". The drafters stressed however, that, they "do not ask that WIPO abandon efforts to promote the appropriate protection of intellectual property, or abandon all efforts to harmonize or improve these laws" but "insist that WIPO work from the broader framework described in the 1974 agreement with the UN, and take a more balanced and realistic view of the social benefits and costs of intellectual property rights as a tool, but not the only tool, for supporting creative intellectual activity". Geneva Declaration, referring to Agreement between the UN and WIPO, 17 December 1974, at Article 1. See also Helfer, supra note 4, at pp. 1010-1012 and James Boyle, "A Manifesto on WIPO and the Future of Intellectual Property" (2004) Duke Law and Technology Review, Vol. 9. 
123 Draft 9 May 2005, available at http://www.cptech.org/a2k/. The A2K Treaty is part of the WIPO Development Agenda. See WIPO, Proposal by Argentina and Brazil for the Establishment of a Development Agenda for the WIPO, WO/GA/31/11, 27 August 2004. The WIPO Development Agenda was subsequently launched (WO/GA/31/15, 5 October 2004; for further developments, see http://www.wipo. int/ip-development/en/agenda/).

124 Ibid. A2K Treaty, at Articles 3-1, 3-5, 3-6, 3-9, 5 and 6 respectively. See also Brian Fitzgerald, Anne Fitzgerald, Mark Perry, Scott Kiel-Chisholm, Erin Driscoll, Dilan Thampappilai, Jessica Coates, "Creating a Legal Framework for Copyright Management of Open Access within the Australian Research Sector, OAK Law Project Report No 1, August 2006, Queensland, at pp. 99-102.

125 Helfer, supra note 4, at p. 1014.

126 See Netherlands Council for Culture, supra note 102.

127 Vaidhyanathan, for example, questions the role of Google as ubiquitous search engine and asks whether public libraries may be more appropriate to administer knowledge. He notes: "It is important to remember that Google serves its own masters: its stockholders and its partners. It does not serve the people of the State of Michigan or the students and faculty of Harvard University. The real risk of privatization is simple: companies fail. Libraries and universities last. Companies wither and crash. Should we entrust our heritage and collective knowledge to a company that has been around for less than a decade?". See Vaidhyanathan, "The Googlization of Everything and the Future of Copyright", supra note 27, at p. 1220. For a more optimistic vision of Google's role, see Leslie A. Kurtz, "Copyright and the Human Condition" (2007) UC Davis Law Review, Vol. 40, pp. 1233-1252, at pp. 1250-1251.

128 John G. Palfrey, Jr. and Robert Rogoyski, "The Move to the Middle: The Enduring Threat of 'Harmful' Speech to the End-to-End Principle" (2006) Washington University Journal of Law and Policy, Vo. 21, pp. 31-65.

129 The principle of net(work) neutrality or in its broader sense, the end-to-end principle, essentially hold that the network should be neutral to the passed content and that intermediaries should pass all packets, while the intelligence is located at the edges of the network where necessary. For excellent account of the "net neutrality" discussions, see Susan P. Crawford, "Network Rules" (2006) Benjamin N. Cardozo School of Law Working Paper No 159; Tim Wu, "Network Neutrality, Broadband Discrimination" (2003) Journal on Telecommunications and High Technology Law, Vol. 2, pp. 41 et. seq.

130 Rosemary J. Coombe, "Protecting Cultural Industries to Promote Cultural Diversity: Dilemma for International Policy-Making Posed by the Recognition of Traditional Knowledge" in Keith E. Maskus and Jerome H. Reichman (eds.), International Public Goods and Transfer of Technology under a Globalized Property Regime, Cambridge: Cambridge University Press, 2005, pp. 559-614, at p. 613. WIPO has stated in this regard: "Challenges of multiculturalism and cultural 
diversity, particularly in societies with both indigenous and immigrant communities, require cultural policies that maintain a balance between the protection and preservation of cultural expressions - traditional or otherwise - and the free exchange of cultural experiences. Mediating between the preservation of cultural heritage and cultural distinctiveness on the one hand, and the nurturing and nourishing of 'living' culture as a source of creativity and development on the other, is another challenge". See WIPO IGC, supra note 1, Annex, at para. 4.

131 For a critique, see Anupam Chander and Madhavi Sunder, "The Romance of the Public Domain" (2004) California Law Review, Vol. 92, pp. 1331-1373.

132 Brown, "Heritage Trouble", supra note 43, at p. 51. Without such a balance, what emerges may be what Tyler Cowen calls the "paradox of diversity": "The world as a whole may be more diverse if some societies refuse to accept diversity as a value. Those cultures will continue to generate highly unique creations, given their status as cultural outliers'. Conversely, generalized diversity may produce greater uniformity because of the cultural blending it inevitably produces". Cowen clarified however that the paradox of diversity may not hold true for all social changes and that some manifestations of wealth and technology increase diversity across the board. See Cowen, Creative Destruction, supra note 104, at p. 146. See also Rosemary J. Coombe, "Fear, Hope, and Longing for the Future of Authorship and a Revitalized Public Domain in Global Regimes of Intellectual Property" (2003) DePaul Law Review, Vol. 52, pp. 1171 et. seq., at p. 1185.

133 See Webster, Theories of Information Society, supra note 57.

134 Patricia L. Bellia, Paul Schiff Berman and David G. Post, Cyberlaw: Problems of Policy and Jurisprudence in the Information Age, Eagan, MN: West Group, 2006, at p. 1. See also Castells, supra note 57. Castells noted that, "[t] he potential integration of text, images, and sounds in the same system, interacting from multiple points, in chosen time (real and delayed) along a global network, in conditions of open and affordable access, does fundamentally change the character of communication. And communication decisively shapes culture..." (ibid. at p. 356).

135 The WIPO model of protection follows a number of principles, among which, the principle of responsiveness to aspirations and expectations of relevant communities, which recognises indigenous and customary laws and protocols and promotes complementary use of positive and defensive protection measures. The principle of flexibility and comprehensiveness recognises further that effective and appropriate protection may be achieved by a wide variety of legal mechanisms, and that too narrow or rigid an approach at the level of principle may constrain effective protection. Protection may accordingly draw on a comprehensive range of options, combining proprietary, non-proprietary and non-IP measures, and using existing IP rights, sui generis extensions or adaptations of IP rights, and specially-created sui generis IP measures and systems, including both defensive and positive measures. Private property rights should complement and be carefully balanced with non-proprietary measures. The principle of recognition of the specific nature and 
characteristics of cultural expression ensures that protection responds to the traditional character of TCE, namely their collective, communal and intergenerational character; their relationship to a community's cultural and social identity and integrity, beliefs, spirituality and values; their often being vehicles for religious and cultural expression; and their constantly evolving character within a community. The WIPO model is complementary to TCE protection applicable under other IP laws, laws and programmes for the safeguarding, preservation and promotion of cultural heritage, and other legal and non-legal measures available for the protection and preservation of TCE. See WIPO IGC, supra note 8, Annex, at pp. 7-9 and Article 10.

136 Michael F. Brown, "Heritage as Property" in Katherine Verdery and Caroline Humphrey (eds.), Property in Question: Value Transformation in the Global Economy, Oxford/New York: Berg, 2004, pp. 49-68, at p. 60.

137 elFL-IP "Advocacy for Access to Knowledge: Copyright and Libraries" is, for instance, a programme to raise awareness in copyright issues for libraries in 50 developing and transition countries. The goal is to build capacity and expertise amongst the elFL.net library community and to represent the interests of members in key international policy for a, such as WIPO, UNESCO and the WTO. It seeks to clarify the role of digital technologies in transforming the way libraries work and fully considering the role of libraries to collect, organise, preserve and make available the world's cultural and scientific heritage for current and future generations (in particular publicly funded libraries operating for the public benefit support access to knowledge, as well as education and training, critical to developing nations whose human resource is central to their advancement. See http://www.eifl.net/.

138 See Dutfield, supra note 106, at p. 75.

139 "Once we admit that there is room for newness - that there are vastly more conceivable possibilities that realized outcomes - we must confront the fact that there is no special logic behind the world we inhabit, no particular justification for why things are the way they are. Any number of arbitrarily small perturbations along the way could have made the world as we know it turn out very differently". See Paul Romer, "New Goods, Old Theory and the Welfare Costs of Trade Restrictions" (1994) Journal of Development Economics, Vol. 43, pp. 5-38, at p. 9.

140 Brown, supra note 135, at p. 62. As Brown lucidly puts it, "[t]o imagine other ways of helping indigenous peoples to maintain the integrity and vitality of their cultures we must first acknowledge that totalizing, legalistic approaches are incompatible with the diversity of values they claim to promote. The powerful norming and rationalizing currents of formal law cannot readily accommodate the situation-specific negotiations required to ensure the dignity of indigenous cultural life in pluralistic states. Although broadly framed rights policies are useful instruments for bringing contending parties to the negotiating table, every additional degree of specificity increases the likelihood that laws will produce unintended harm, especially when confronting the complex, dynamic quality of living cultures". Brown, ibid. at p. 60. 